\title{
Furrow diking and the economic water use efficiency of irrigated cotton in the Southeast United States
}

\author{
R. C. Nuti ${ }^{1}$, C. C. Truman ${ }^{2}$, L. J. Krutz ${ }^{3}$, R. B. Sorensen ${ }^{1}$ \\ \& M. C. Lamb ${ }^{1}$ \\ ${ }^{1} U S D A-A R S$, Dawson, Georgia, USA \\ ${ }^{2}$ USDA-ARS, Tifton, Georgia, USA \\ ${ }^{3} U S D A-A R S$, Stoneville, Mississippi, USA
}

\begin{abstract}
Cotton (Gossypium hirsutum L.) production in the Southeast United States can be limited by periodic drought. Irrigation and furrow diking tillage may improve economic yield and water use efficiency of cotton. Timing of rainfall may interfere with the efficiency of irrigation. Field studies were conducted during 2001 to 2010 near Shellman, Georgia to examine four irrigation rates based on Irrigator Pro for Cotton consisting of 100, 66, 33, and $0 \%$. The objectives were to determine the value of irrigation and the economic water use efficiency of irrigation among irrigation rates over years. In-season rainfall ranged from 270 to $760 \mathrm{~mm}$ and irrigation volume ranged from 110 to $455 \mathrm{~mm}$. Total water applied (rainfall + irrigation) ranged between 560 and $870 \mathrm{~mm}$. In all but 2003, irrigation improved yield by $247-645 \mathrm{~kg}$ lint $\mathrm{ha}^{-1}$. Years with average or below average rainfall had incrementally higher yields as irrigation rate increased except for 2007. Water use efficiency for irrigation was highest for the $33 \%$ rate in 2001 and 2002 and higher in 2004 and 2007 for the 66\% rate. In severe drought years, the $33 \%$ rate did not sufficiently relieve drought stress. Irrigation provided profit in all but one year of the study. Although 100\% irrigation is not the most efficient irrigation level, it often provides the most economic return. Furrow diking improved yield and water use efficiency in 3 of 6 years tested.
\end{abstract}

Keywords: furrow diking, irrigation, water use efficiency, tillage, cotton, Gossypium hirsutum. 


\section{Introduction}

Cotton (Gossypium hirsutum L.) production has had a major historical impact in the Southeast United States. In 2010, cotton was planted on 4.4 million ha in the US and on 526,000 ha in Georgia. The recent United States Census of Agriculture, reports that $59 \%$ of cotton in Georgia is irrigated (USDA-NASS [1]). Current agricultural water issues and the need for reduced input costs in farming operations add importance to making sound water use decisions to ensure efficient management of resources as well as ensuring stable profitability for growers. The Southeast US production region receives an average precipitation of $1,300 \mathrm{~mm}$ annually which is usually delivered in high intensity storms; however periodic drought is also frequent (Sheridan et al. [2]; Bosch et al. [3]). Limited soil infiltration during intense storms often limits soil water capture and storage during precipitation making supplemental irrigation necessary to match crop water use during these periods to achieve high stable yields. Sorensen et al. [4] reported a 10 to 50\% cotton yield improvement with irrigation compared to non-irrigated cotton in Georgia. In North Carolina, Nuti et al. [5] showed that cotton yield improved between 15 and 50\% with irrigation compared to non-irrigated cotton. Limited or reduced rate irrigation may be used to reduce the amount of fresh water used in agriculture. With current predictions for population expansion and the reduction in land available for agricultural production, production efficiency and capacity must increase to meet demand.

Depending on the level of discussion, water use efficiency (WUE) has many definitions. At the plant cellular level, WUE is considered to be the units of water transpired per unit of carbon gain. For irrigation, WUE is the amount of water applied compared to the harvestable crop produced. On an agricultural economic basis, WUE is the ratio between the cost per unit of water applied in relation to the value of the crop produced (Lamb et al. [6]).

Furrow diking tillage creates a series of basins and dams between crop rows to increase infiltration opportunity time and reduce runoff of both rain and irrigation water (Lyle and Dixon [7]; Nuti et al. [8]; Jones and Stewart [9]). If a greater portion of rainfall was captured in the field, irrigation requirements have the potential to be reduced, thus improving agronomic WUE and lower energy use associated with irrigation. Nuti showed that furrow diking reduced irrigation requirements and improved crop value with furrow diking in one of 3 years. The objectives of these field studies were to [1] measure the agronomic and economic value of cotton produced among multiple rates of irrigation compared to nonirrigated cotton, [2] quantify the value that irrigation has on a unit basis in terms of cotton production over multiple years, and [3] evaluate furrow diking tillage among irrigation rates over years. The irrigation rate experiment is reported for 2001 to 2008 to address objectives 1 and 2. The furrow diking over irrigation rate study is reported for 2005 to 2010 to address objective 3 . 


\section{Materials and methods}

In 2001 to 2010, four irrigation rates were evaluated on cotton at the USDAARS Multicrop Irrigation Farm near Shellman, Georgia $\left(84^{\circ} 36^{\prime} \mathrm{W}, 30^{\circ} 44^{\prime} \mathrm{N}\right)$ on a Greenville fine sandy loam (fine, kaolinitic, thermic Rhodic Kandiudults) with $0-2 \%$ slope. Cotton was produced under conventional tillage with best management practices (Brown et al. [10]). Cultivar 'DP 458' (Delta and Pine Land Company; Scott, Mississippi) was used in 2001 and 2002 and cultivar 'DP 555BG/RR' was planted in 2003-2010. Irrigator Pro for Cotton was used to schedule irrigation timing (Nuti et al. [8]; Davidson et al. [11]). The model is designed to avoid crop stress while triggering irrigation at the most efficient timing and volume to avoid over-irrigation [10]. Irrigator Pro for Cotton is based on daily soil water potential (Watermark soil moisture sensor, Irrometer; Riverside, California) at $0.2,0.4$, and $0.6 \mathrm{~m}$. The software uses a weighted system over the 3 depths where the sensor at $0.2 \mathrm{~m}$ contributes $43 \%$ of the average compared to $32 \%$ at $0.4 \mathrm{~m}$ and $25 \%$ at $0.6 \mathrm{~m}$ depths. When this weighted average reaches $-50 \mathrm{kPa}$, the software will recommend irrigation. Soil water potential was corrected using a common $50 \mathrm{~mm}$ soil temperature recorded at 04:00 daily.

Table 1: $\quad$ Seasonal rain accumulation and irrigation totals for irrigated cotton near Shellman, Georgia.

\begin{tabular}{|c|c|c|c|c|}
\hline Year & Rainfall $\dagger$ & Irrigation $\uparrow$ & Total water & Irrigation cost $\S$ \\
\hline & & & . & $-\$ \mathrm{ha}^{-1}-$ \\
\hline 2001 & 551 & 267 & 818 & 260 \\
\hline 2002 & 274 & 285 & 559 & 277 \\
\hline 2003 & 729 & 137 & 866 & 133 \\
\hline 2004 & 673 & 152 & 825 & 148 \\
\hline 2005 & 762 & 109 & 871 & 106 \\
\hline 2006 & 414 & 455 & 869 & 443 \\
\hline 2007 & 270 & 410 & 680 & 399 \\
\hline 2008 & 589 & 246 & 835 & 239 \\
\hline 2009 & 907 & 152 & 1059 & 148 \\
\hline 2010 & 414 & 305 & 719 & 297 \\
\hline
\end{tabular}

$\uparrow$ Reported rainfall totals are the annual accumulation from planting to crop termination.

\$Irrigation rate and timing were dictated by Irrigator Pro for Cotton and are shown at the full amount recommended.

§Irrigation cost shown is for the full rate recommended by Irrigator Pro for Cotton at $\$ 0.973 \mathrm{ha}^{-1} \mathrm{~mm}$.

A three tower linear overhead irrigation system was used that had separate nozzle packages on each tower to achieve different irrigation rates under the same pressure. The non-irrigated treatment was planted in a range beyond the irrigation system. The four rates applied were $100,66,33$, and $0 \%$ of the full rate recommended by Irrigator Pro for Cotton. Irrigation, at respective rates, was applied to all plots at the same time. Irrigation treatments were replicated three 
times and were arranged in a strip-plot design (Gomez and Gomez [12]). In 2005 , furrow diking was added to the experiment in each of the irrigation treatments. In 2005 to 2010, irrigation rate was the main-plot factor and furrow diking was the sub-plot factor within each irrigation rate. The furrow diked and non-furrow diked sub-plots were $3.6 \times 30.5 \mathrm{~m}$. Furrow dikes were established after crop emergence each year. Rainfall, irrigation, total water, and the cost of application are shown for the $100 \%$ irrigation treatment in Table 1 .

Cotton was machine picked from the middle two rows for the full length of each sub-plot and a sub-sample $(200 \mathrm{~g})$ of seedcotton was ginned to determine lint turnout. Lint yield was used to calculate crop value at $\$ 1.595 \mathrm{~kg}^{-1}$ of lint. Irrigation costs were calculated considering that the energy required for applying $1 \mathrm{~mm}$ of water $\mathrm{ha}^{-1}$ was $\$ 0.973$. Net returns were calculated assuming the production costs between treatments other than irrigation rate were equal. For the purposes of these studies, other production costs are not reflected in the net return values and are assumed to be equal among treatments. In each respective replication in each year, the non-irrigated yield was subtracted from each of the irrigated yields to calculate the yield and crop value gained by each irrigation rate and furrow diking treatment, less the respective irrigation and/or furrow diking costs. This yield was then used to calculate the irrigation use efficiency by dividing the additional yield by the amount of water applied to the respective irrigation rate treatments for each year.

Data for each of these studies were combined over years and analyzed in SAS (version 9.1) under the general linear model and means were separated using Fisher's Protected LSD at $\alpha \leq 0.05$. A significant year $\times$ irrigation rate interaction was present for yield in the irrigation rate study during 2001 to 2008, so years are reported separately. In the furrow diking by irrigation rate study during 2005 to 2010, further statistical analysis was carried out to identify years with similar responses in order to draw more concise conclusions in which 3 groups were identified.

\section{Results and discussion}

Rainfall, irrigation, and total water applied during the growing season to the $100 \%$ irrigation rate treatment are reported in Table 1. The irrigation costs for the full irrigation rate $\mathrm{ha}^{-1}$ were calculated based on the energy required to apply water at $\$ 0.973 \mathrm{ha}^{-1} \mathrm{~mm}$.

\subsection{Irrigation rate study: 2001 to 2008}

\subsubsection{Lint yield and irrigation}

A positive response was observed to irrigation in the 8 years of the study except in 2003, which received more than average precipitation (Table 2). In 2005, also a wet year, the 3 irrigation rate treatments produced similar yields which were $25 \%$ greater than non-irrigated cotton. In the remaining 6 years studied, increased irrigation rates were generally associated with increased cotton yield. 
Table 2: Effect of irrigation rate on cotton lint yield over years near Shellman, Georgia.

\begin{tabular}{lcrrrrrrr}
\hline $\begin{array}{l}\text { Irrigation } \\
\text { Rate }\end{array}$ & 2001 & 2002 & 2003 & 2004 & 2005 & 2006 & 2007 & 2008 \\
\cline { 2 - 8 } & & & & \multicolumn{7}{c}{$\mathrm{kg} \mathrm{ha}^{-1}$} \\
$0 \%$ & $645 \mathrm{C} \dagger$ & $241 \mathrm{D}$ & $1022 \mathrm{~A}$ & $354 \mathrm{D}$ & $1118 \mathrm{~B}$ & $450 \mathrm{D}$ & $415 \mathrm{C}$ & $540 \mathrm{C}$ \\
$33 \%$ & $1060 \mathrm{~B}$ & $887 \mathrm{C}$ & $988 \mathrm{~A}$ & $635 \mathrm{C}$ & $1365 \mathrm{~A}$ & $949 \mathrm{C}$ & $797 \mathrm{~B}$ & $842 \mathrm{BC}$ \\
$66 \%$ & $1123 \mathrm{AB}$ & $1084 \mathrm{~B}$ & $972 \mathrm{~A}$ & $1331 \mathrm{~B}$ & $1404 \mathrm{~A}$ & $1393 \mathrm{~B}$ & $1600 \mathrm{~A}$ & $1134 \mathrm{AB}$ \\
$100 \%$ & $1225 \mathrm{~A}$ & $1290 \mathrm{~A}$ & $1060 \mathrm{~A}$ & $1572 \mathrm{~A}$ & $1426 \mathrm{~A}$ & $1610 \mathrm{~A}$ & $1770 \mathrm{~A}$ & $1365 \mathrm{~A}$ \\
\hline
\end{tabular}

$\uparrow$ Means in a column followed by the same letter are not statistically different according to Fisher's Protected LSD at $\alpha=0.05$.

In 2002, 2004, and 2006, each irrigation rate produced significantly more cotton than the next lower rate. In each of these respective years, the $100 \%$ irrigation rate treatment produced 5.4, 4.4, and 3.6 times more cotton than the non-irrigated treatment. In 2001, Cotton irrigated at 33\% had a similar yield to cotton irrigated at $66 \%$, which was similar compared to the full irrigation rate. In 2007 , the lowest irrigation rate produced $92 \%$ more lint than the non-irrigated treatment, but still yielded less than $50 \%$ of the 2 higher irrigation rates. It was obvious that yield limiting stress was not avoided in the $33 \%$ irrigation rate treatment in 2007. Although 2008 received greater than 2 times the rainfall that was received in 2007 , the $100 \%$ irrigation rate produced $30 \%$ less lint compared to the same treatment in 2007. Non-irrigated yield ranged between 241 and $1,118 \mathrm{~kg} \mathrm{ha}^{-1}$ over the 8 years. Considering that the two highest non-irrigated yields were achieved with an average of $745 \mathrm{~mm}$ rainfall in 2003 and 2005, one would assume that the non-irrigated yield in 2004 with $673 \mathrm{~mm}$ rainfall during the growing season would have been much greater than $354 \mathrm{~kg} \mathrm{ha}^{-1}$. It would certainly not be assumed that an 11\% increase in rainfall between 2004 and the average of 2003 and 2005 could allow a 3 fold increase in yield as was found in this study. These yield results indicate that cotton yield stability without irrigation is very poor in the region studied.

\subsubsection{Irrigated crop value in excess of non-irrigated yield}

To evaluate the value of cotton produced by irrigation rates compared to the nonirrigated potential each year, the non-irrigated yield was subtracted from the yield produced by each irrigation rate (Table 3). In 2003, a net loss of $\$ 74$ to $\$ 222 \mathrm{ha}^{-1}$ was measured among irrigation rates compared to non-irrigated cotton. In 2001 and 2005, irrigated cotton produced similar average crop values of $\$ 613$ and $\$ 377 \mathrm{ha}^{-1}$, respectively, in addition to the non-irrigated yield, regardless of irrigation rate. An incremental increase in crop value was observed among irrigation rates in 2002 with an average of a $22 \%$ increase in value between irrigation rates. In 2004, the same trend was observed, but the difference between the 33 and $66 \%$ irrigation rates was 3.7 times the value compared to a $23 \%$ increase between the $66 \%$ rate and full irrigation. The 66 and $100 \%$ irrigation rates produced similar crop values in each of 2006 and 2007, which 
Table 3: Effect of irrigation rate on net return to irrigation rate over years near Shellman, Georgia. ${ }^{\dagger}$

\begin{tabular}{|c|c|c|c|c|c|c|c|c|}
\hline $\begin{array}{l}\text { Irrigation } \\
\text { Rate }\end{array}$ & 2001 & 2002 & 2003 & 2004 & 2005 & 2006 & 2007 & 2008 \\
\hline $33 \%$ & $576 \mathrm{~A}$ & $946 \mathrm{C}$ & $-99 \mathrm{~A}$ & $395 \mathrm{C}$ & $358 \mathrm{~A}$ & $660 \mathrm{~B}$ & $480 \mathrm{~B}$ & $413 \mathrm{~B}$ \\
\hline $66 \%$ & $593 \mathrm{~A}$ & $1166 \mathrm{~B}$ & $-222 \mathrm{~A}$ & $1458 \mathrm{~B}$ & $388 \mathrm{~A}$ & $1221 \mathrm{~A}$ & $1626 \mathrm{~A}$ & $796 \mathrm{AB}$ \\
\hline $100 \%$ & $670 \mathrm{~A}$ & $1401 \mathrm{~A}$ & $-74 \mathrm{~A}$ & $1791 \mathrm{~A}$ & $385 \mathrm{~A}$ & $1416 \mathrm{~A}$ & $1760 \mathrm{~A}$ & $1080 \mathrm{~A}$ \\
\hline
\end{tabular}

$\uparrow$ Net return to irrigation rate is calculated as the value of lint produced by irrigation above nonirrigated yield considering lint value at $\$ 1.595 \mathrm{~kg}^{-1}$ and the cost of irrigation was $\$ 0.973 \mathrm{ha}^{-1} \mathrm{~mm}$. \$Means in a column followed by the same letter are not statistically different according to Fisher's Protected LSD at $\alpha=0.05$.

were 2 and 3.5 times greater than the crop value increase over non-irrigated cotton produced by the $33 \%$ irrigation rate in each respective year. In 2008 , the lowest irrigation rate produced $\$ 413 \mathrm{ha}^{-1}$ more crop value than non-irrigated cotton that year and the full irrigation rate produced 2.6 times the crop value compared to non-irrigated cotton.

\subsubsection{Crop value per unit of water application cost}

The variable rainfall, irrigation requirements, and yields over years warrants investigation into which irrigation rates may have the highest economic irrigation WUE. The dollar value of lint produced by each irrigation rate in addition to the next lower irrigation rate was divided by the amount of water applied to achieve the yield (Table 4). Since negative returns were observed in 2003 , negative WUE values were also observed. The $33 \%$ rate lost $\$ 0.91 \mathrm{ha}^{-1}$ $\mathrm{mm}$ applied compared to non-irrigated cotton in 2003, simply because it produced lower yield than the non-irrigated cotton. The $100 \%$ rate only lost $\$ 0.24 \mathrm{ha}^{-1} \mathrm{~mm}$, because the yield was numerically higher than non-irrigated cotton, however the amount spent on irrigation was not enough to justify irrigation in that year. In 2001, 2002, 2005, 2006, and 2008, the general trend was that the $33 \%$ irrigation rate was the most effective at producing crop value per unit of water used. In 2004 and 2007, irrigation applied at 66\% was the most efficient at producing crop value. The greatest economic irrigation WUE was achieved by the 2 higher irrigation rates in 2004 ( $\$ 4.72$ to $\$ 5.91$ in crop value ha ${ }^{-}$ ${ }^{1} \mathrm{~mm}$ ). This result was possible because the non-irrigated yield in 2004 was the second lowest behind 2002, and the $100 \%$ irrigation rate yield was third highest in the study. The second greatest display of economic irrigation WUE was by the $33 \%$ irrigation rate in 2002 and 2005 (\$4.06 to $\$ 4.09$ in crop value ha ${ }^{-1} \mathrm{~mm}$ ). In 2002, this was a result of a very low non-irrigated yield $\left(241 \mathrm{~kg} \mathrm{ha}^{-1}\right)$ associated with a good response to the low rate of irrigation, a 3.7 fold increase over non-irrigated cotton. In 2005, the $33 \%$ irrigation rate had a significant yield improvement over non-irrigated cotton $\left(247 \mathrm{~kg} \mathrm{ha}^{-1}\right.$ or $\left.22 \%\right)$ with only $36 \mathrm{ha}^{-1}$ $\mathrm{mm}$ irrigation applied resulting in a high efficiency in producing crop value per unit of water applied. 
Table 4: $\quad$ Value of cotton lint produced per unit of irrigation water applied over years near Shellman, Georgia. ${ }^{\dagger}$

\begin{tabular}{lcccccccc}
\hline $\begin{array}{l}\text { Irrigation } \\
\text { Rate }\end{array}$ & 2001 & 2002 & 2003 & 2004 & 2005 & 2006 & 2007 & 2008 \\
\cline { 2 - 8 } & & & \multicolumn{7}{c}{$\$ \mathrm{~mm}^{-1}$ water ha ${ }^{-1}$} & & & & & \\
$33 \%$ & $2.68 \mathrm{~A} \$$ & $4.09 \mathrm{~A}$ & $-0.91 \mathrm{~A}$ & $3.15 \mathrm{C}$ & $4.06 \mathrm{~A}$ & $1.77 \mathrm{~A}$ & $1.42 \mathrm{~B}$ & $2.05 \mathrm{~A}$ \\
$66 \%$ & $1.38 \mathrm{~B}$ & $2.52 \mathrm{~B}$ & $-1.02 \mathrm{~A}$ & $5.91 \mathrm{~A}$ & $2.02 \mathrm{~A}$ & $1.65 \mathrm{~A}$ & $2.44 \mathrm{~A}$ & $1.97 \mathrm{~A}$ \\
$100 \%$ & $1.02 \mathrm{~B}$ & $2.00 \mathrm{C}$ & $-0.24 \mathrm{~A}$ & $4.72 \mathrm{~B}$ & $1.46 \mathrm{~A}$ & $1.26 \mathrm{~A}$ & $1.73 \mathrm{~B}$ & $1.77 \mathrm{~A}$ \\
\hline
\end{tabular}

$\dagger$ Value of lint per unit of water applied is net return to irrigation over $\mathrm{mm}$ of water applied considering water cost at $\$ 0.973 \mathrm{ha}^{-1} \mathrm{~mm}$ and lint value at $\$ 1.595 \mathrm{~kg}^{-1}$.

$\$$ Means in a column followed by the same letter are not statistically different according to Fisher's Protected LSD at $\alpha=0.05$.

\subsection{Furrow diking and irrigation rate study: 2005 to 2010}

\subsubsection{Lint yield}

In 2005 to 2010, there was a significant interaction between years for yield. Years were grouped by yield response and rainfall patterns to establish environmental groups. The groups were 2005 and 2009 (wet), 2007 (dry), and 2006, 2008, and 2010 (moderate). When analyzed by groups, there were no interactions for yield among years within a group, thus results are reported according to these environmental groups. There was no interaction between irrigation rate and furrow diking and the response to furrow diking is reported over irrigation rate for each environmental group (Table 5). In both wet and dry years, there was no yield benefit to furrow diking. In moderate years, furrow diked cotton averaged $150 \mathrm{~kg} \mathrm{ha}^{-1}$ more lint than conventionally tilled cotton. This $16 \%$ increase is averaged over irrigation rates and occurred every other year during the study.

Table 5: Effect of furrow diking on cotton lint yield in various environmental groups of years near Shellman, Georgia. ${ }^{\dagger}$

\begin{tabular}{lcrr}
\hline $\begin{array}{l}\text { Environmental } \\
\text { group }\end{array}$ & Wet & Dry & Moderate \\
\cline { 2 - 4 } & $1100 \mathrm{~A}^{\dagger}$ & $\mathrm{kg} \mathrm{ha}^{-1}$ & $1080 \mathrm{~A}$ \\
Furrow diked & $1110 \mathrm{~A}$ & $930 \mathrm{~B}$ \\
Non-furrow diked & $110 \mathrm{~A}$ & $1105 \mathrm{~A}$
\end{tabular}

$\dagger$ Means in a column followed by the same letter are not statistically different according to Fisher's Protected LSD at $\alpha=0.05$.

\subsubsection{Water use efficiency}

The ratio of lint produced per unit of water applied is expressed as WUE in Table 6. Furrow diking did not affect WUE in wet or dry years, however it did improve WUE by $100 \mathrm{~g} \mathrm{~mm}^{-1}$ of water in moderate years. The excess water available through rainfall in wet years reduced WUE by an average of $370 \mathrm{~g} \mathrm{~mm}^{-1}$ of water. Water use efficiency was high in dry years because water was limited 
and runoff was minimal. Furrow diked cotton in moderate years was more efficient because surface applied water was retained and available for plant use (Truman and Nuti [13]).

Table 6: Effect of furrow diking on water use efficiency in various environmental groups of years near Shellman, Georgia. ${ }^{\dagger}$

\begin{tabular}{|c|c|c|c|}
\hline $\begin{array}{l}\text { Environmental } \\
\text { group }\end{array}$ & Wet & Dry & Moderate \\
\hline & \multicolumn{3}{|c|}{-g lint $\mathrm{mm}^{-1}$ water ${ }^{\dagger}$} \\
\hline Furrow diked & $640 \mathrm{~A}^{\ddagger}$ & $1030 \mathrm{~A}$ & $820 \mathrm{~A}$ \\
\hline Non-furrow diked & $660 \mathrm{~A}$ & $1020 \mathrm{~A}$ & $720 \mathrm{~B}$ \\
\hline
\end{tabular}

\section{Conclusions}

The variability in cotton yield, value $\mathrm{ha}^{-1}$, and economic WUE in response to irrigation rates over years shows that irrigation is necessary for long term yield and profit stability to cotton growers in the Southeast US. Although irrigation was not necessary for achieving significantly greater yield and profit in 1 of 8 years of the irrigation rate study, having the option to irrigate reduces overall risk and improves profit potential when used in the other years. Best management practices for irrigation should emphasize accurate irrigation scheduling to maximize economic WUE and profit. As reported here, higher WUE may be achieved by reducing irrigation rates, however the greatest profit per unit land area remains the goal of growers and must be achieved. Non-irrigated cotton produced yield above a breakeven threshold of $\$ 1,500 \mathrm{ha}^{-1}$ in only $2003(\$ 1,630$ $\left.\mathrm{ha}^{-1}\right)$ and $2005\left(\$ 1,783 \mathrm{ha}^{-1}\right)$ during this study. The greatest yield potential was present in 2004, 2006, and 2007, which were years that required irrigation to provide an overall profit. In 2001, 2002, 2004, 2006, and 2008, the upper limit of economic potential ha ${ }^{-1}$ was not reached leaving the opportunity to increase yield with more intense water management. For non-irrigated cotton production, management should be driven to reduce production costs to make the breakeven threshold more attainable.

Furrow diking provided a significant benefit in 3 of the six years tested. This benefit was achieved by taking advantage of surface applied water from rainfall and irrigation. The 3 years that furrow diking did not provide a benefit had either an abundance of rain or severe drought. The positive side is that the average benefit of furrow diking outweighed the cost of the practice for the years without a yield benefit. Furrow diking is a practice that may aid in improving economic WUE and reduce risk in cotton production in the Southeast United States. 


\section{References}

[1] United States Department of Agriculture - National Agricultural Statistics Service (USDA-NASS) Census of Agriculture. 2007. Available at: www.agcensus.usda.gov

[2] Sheridan, J.M., Knisel, W.G., Woody, T.K. \& Asumssen, L.E., Seasonal variation in rainfall and rainfall-deficient periods in this southern coastal plain and flatwoods region of Georgia. Res. Bull., 243, Univ. of Georgia College of Agriculture Experiment Stations, Athens, Georgia, 1979.

[3] Bosch, D.D., Sheridan, J.M. \& Davis, F.M., Rainfall characteristics and spatial correlation for the Georgia coastal plain. Trans. Am. Soc. Ag. Eng., 42, pp. 1637-1644, 1999.

[4] Sorensen, R.B., Bader, M.J \& Wilson, E.H., Cotton yield and grade response to nitrogen applied daily through a subsurface drip irrigation system. Appl. Eng. Agric., 20(1), pp. 13-16, 2004.

[5] Nuti, R.C., Casteel, S.N., Viator, R.P., Lanier, J.E., Edmisten, K.L., Jordan, D.L., Grabow, G.L., Barnes, J.S., Mathews, J.W. \& Wells, R., Management of cotton grown under overhead sprinkle and sub-surface drip irrigation. J. Cotton Sci., 10, pp. 76-88, 2006.

[6] Lamb, M.C., Sorensen, R.B., Nuti, R.C., Butts, C.L., Faircloth, W.H. \& Eigenberg, D., Agronomic and economic effect of irrigation rate in corn. Agron. J., In press.

[7] Lyle, W.M, \& Dixon, D.R., Basin tillage for rainfall retention. Trans. Am. Soc. Ag. Eng., 20, pp. 1013-1017, 1021, 1977.

[8] Nuti, R.C., Lamb, M.C., Sorensen, R.B. \& Truman, C.C., Agronomic and economic response to furrow diking tillage in irrigated and non-irrigated cotton (Gossypium hirsutum L.). Ag. Wat. Manage., 96, pp. 1078-1084, 2009

[9] Jones, O.R. \& Stewart, B.A., Basin tillage. Soil and Tillage Research, 18, pp. 249-265, 1990.

[10] Brown, S.M., Culpepper, S., Harris, G., Kemerait, B., Roberts, P., Shurley, D. \& Ziehl, A., 2008 Georgia cotton production guide. UGA Publ. CSS08-01. Univ. of Georgia, Athens. Available at: commodities.caes.uga.edu /fieldcrops/cotton/2008cottonguide/2008CottonGuide.htm

[11] Davidson, J. I., Jr., Griffin, W.J., Lamb, M.C., Williams, R.G. \& Sullivan, G., Validation of Exnut for scheduling peanut irrigation in North Carolina. Peanut Sci., 25, pp. 50-58, 1998.

[12] Gomez, K.A. \& Gomez, A.A., Statistical Procedures for Agricultural Research, $2^{\text {nd }} \mathrm{ed}$. John Wiley \& Sons Inc: Indianapolis, Indiana, 1984.

[13] Truman, C.C \& Nuti, R.C., Improved water capture and erosion reduction through furrow diking. Agric. Water Manage., 96, pp. 1071-1077, 2009. 